\title{
PELAKSANAAN PENGALIHAN HAK ATAS TANAH MENJADI TANAH WAKAF (STUDI DI KANTOR URUSAN AGAMA KEACAMATAN DATUK BANDAR KOTA TANJUNG BALAI)
}

\author{
Sunarto ${ }^{1)}$ \\ ${ }^{1)}$ Fakultas Hukum Universitas Darmawangsa \\ email: sunarto@dharwangsa.ac.id ${ }^{1)}$
}

\begin{abstract}
ABSTRAK
Secara terminologi wakaf dipandang sebagai penyerahan suatu benda dengan dibekukan atau ditahan benda tersebut dengan diambilnya suatu manfaat dari wujud benda itu sendiri. Status kepemilikan hak atas tanah terkadang melibatkan lebih dari satu pihak sebagai pemilik hak atas tanah. Kepemilikan suatu tanah dapat terjadi karena pewarisan, wasiat, hibah dan jual beli termasuk perwakafan. Hal ini yang menjadi poin penting dalam penelitian ini. Tanah-tanah yang akan diwakafkan harus bisa dipastikan pada saat perwakafan suatu tanah tidak akan terjadi suatu sengketa baik bagi yang mewakafkan dengan pihak lain yang terkait atas tanah wakaf tersebut. Sehingga dalam perwakafan atas tanah tidak muncul suatu peristiwa dikemudian hari yang merugikan pihak pengelola tanah wakaf. Maka untuk memastikan keabsahan kepemilikan suatu tanah yang akan di wakafkan dilalui dengan pelaksanaan pengalihan hak atas tanah menjadi tanah wakaf sesuai dengan prosedur hukum yang berlaku. Apabila prosedur perwakafan tanah tidak dilalui dengan aturan perlaihan hak atas tanah maka akan timbul permasalahan dikemudian hari.
\end{abstract}

Kata kunci: Pengalihan, Tanah, Menjadi, Tanah, Wakaf.

\section{ABSTRACT}

In terms of waqf, it is seen as the delivery of an object by freezing or holding the object by taking a benefit from the object itself. The status of ownership of land rights sometimes involves more than one party as the owner of land rights. Ownership of a land can occur because of inheritance, wills, grants and buying and selling including waqf. This is an important point in this study. The land to be donated must be ensured that at the time of donating a land, there will be no dispute for the donors with other parties related to the waqf land. So that in waqf land does not appear an event in the future that is detrimental to the manager of the donated land. So to ensure the legality of ownership of a land to be donated, the transfer of land rights to waqf land is carried out in accordance with applicable legal procedures. If the land compensation procedure is not followed with the rules for maintaining land rights, problems will arise in the future.

Key words: Transfer, Land, Becoming, Land, Waqf. 


\section{PENDAHULUAN}

Sedekah adalah suatu perbuatan yang mulia yang datangnya dari hati manusia untuk memberikan suatu kemudahan rezeki bagi yang memberikannya. Penyerahan suatu benda untuk diajadikan suatu wakaf merupakan suatu perbuatan yang mulia yang memberikan sebahagian hartanya untuk kepentingan amal ibadah.

Amal ibadah dengan mewakafkan sebagian hartanya akan menolong setiap orang yang mendapatkan wakaf. Harta benda wakaf peruntukannya sangatlah banyak manfaatnya. Pemanfaatan harta benda wakaf sebesar-besarnya untuk kepentingan umat islam dalam bidang pendidikan berupa pendirian sekolah. Harta benda wakaf juga diperuntukan untuk kepentingan pendirian rumah ibadah dengan mendirikan mesjid serta mushola. Selain itu juga banyak lagi peruntukan harta benda wakaf yaitu membuat tempat perkuburan serta pantia asuhan.

Kegiatan amal ibadah wakaf secara hukum syariat islam mengatur tata cara penyerahan dan penerimaannya termasuk dalam peruntukannya. Hukum islam dan hukum nasional menjamin dan melindungi setiap perbuatan mulia pemberian harta wakaf.

Kegiatan pelaksanaan wakaf dilakukan dengan ketentuanketentuan hukum yang berlaku yang sesuai dengan hukum islam serta hukum nasional. Kegiatan mewakafkan tanah milik sebenarnya telah sah sesaat setelah orang yang mewakafkan (wakif) harta benda yang akan diwakafkan selesai mengucapkan ikrar wakaf kepada orang yang bertugas mengelola tanah wakaf (nadzir) harus dilakukan dihadapan Pejabat Pembuat Akta Ikrar Wakaf (PPAIW) yang berada di Kantor Urusan Agama dan disaksikan oleh dua orang saksi pada saat membacakan ikrar wakaf.

Setelah membacakan ikrar wakaf yang dilaksanakan di pengadilan agama telah dipenuhinya rukun wakaf yaitu Menurut jumhur ulama dari mazhab Syafi'i, Maliki dan Hanbali, mereka sepakat bahwa rukun wakaf ada empat, yaitu: Wakif (orang yang berwakaf), Mauquf 'alaih (orang yang menerima wakaf), Mauquf (harta yang diwakafkan) serta Sighat (pernyataan wakif sebagai suatu kehendak untuk mewakafkan harta bendanya). ${ }^{1}$ Serta menurut Menurut pasal 6 Undang-undang Nomor 41 Tahun 2004, wakaf dilaksanakan dengan memenuhi unsur wakaf sebagai berikut: Wakif, Nadzir, Harta Benda Wakaf, Ikrar Wakaf, Peruntukkan Harta Benda Wakaf serta Jangka Waktu Wakaf. ${ }^{2}$

Kantor Pertanahan akan memproses peralihan harta benda yang diwakafkan misalkan sebidang tanah untuk menjadi atas nama tanah wakaf. Bila surat dari badan pertanahan telah keluar makan telah selesailah hubungan pemilik tanah yang diwakafkan yang terdahulu dengan tanah yang diwakafkan menjadi atas nama wakaf yang telah dibacakan ikrarnya dikantor urusan agama. Peralihan tanah hak milik perseorangan menjadi tanah wakaf merupakan suatu bentuk kepastian

1 Jumhur Ulama Dari Mazhab Syafi'i, Maliki Dan Hanbali, n.d.

2 Menurut Pasal 6 Undang-Undang Nomor 41 Tahun 2004 Tentang Wakaf., n.d. 


\section{Volume 22 No. 2, AGUSTUS 2021 ISSN 2686-5750 (ONLINE) \\ ISSN 1411-0717 (CETAK)}

hukum akan tidak terjadinya persengketaan dikemudian hari. Badan pertanahan harus memastikan bahwa tanah yang diwakafkan tidak dalam persengketaan atau perbuatan lain yang akan terjadi dikemudian hari.

Persoalan dari peralihan tanah hak milik menjadi tanah wakaf adalah berkaitan dengan status kepemilikan atas tanah tersebut. Status kepemilikan hak atas tanah terkadang melibatkan lebih dari satu pihak sebagai pemilik hak atas tanah. Kepemilikan suatu tanah dapat terjadi karena pewarisan, wasiat, hibah dan jual beli termasuk perwakafan. Hal ini yang menjadi poin penting dalam penelitian ini. "Tanah merupakan anugrah dari Tuhan Yang Maha Esa, yang memiliki arti penting dalam kehidupan umat manusia". 3 Tanahtanah yang akan diwakafkan harus bisa dipastikan pada saat perwakafan suatu tanah tidak akan terjadi suatu sengketa baik bagi yang mewakafkan dengan pihak lain yang terkait atas tanah wakaf tersebut. Sehingga dalam perwakafan atas tanah tidak muncul suatu peristiwa dikemudian hari yang merugikan pihak pengelola tanah wakaf. Maka untuk memastikan keabsahan kepemilikan suatu tanah yang akan di wakafkan dilalui dengan

3 Zaid Afif, "Peranan Pejabat Pemerintahan Desa Sebagai Pihak Yang Mengetahui Tentang Jual Beli Tanah (Study Di Desa Gotting Sidodadi Kecamatan Bandar Pasir Mandoge Kabupaten Asahan Sumatera Utara)," Prosiding Seminar Nasional Multidisiplin Ilmu Universitas Asahan 2018 Tema: "Strategi Membangun Penelitian Terapan yang Bersinergi dengan Dunia Industri, Pertanian dan Pendidikan dalam Meningkatkan Daya Saing Global" 06 November 2018, Kisaran, no. November (2018): 463-472. pelaksanaan pengalihan hak atas tanah menjadi tanah wakaf sesuai dengan prosedur hukum yang berlaku. Apabila prosedur perwakafan tanah tidak dilalui dengan aturan perlaihan hak atas tanah maka akan timbul permasalahan dikemudian hari.

Berdasarkan kajian penulis ada persoalan-persoalan yang kemungkinan terjadi pada saat terjadinya perwakafan secara desain dan desolen yaitu antara hukum yang tertulis dengan kenyataan yang terjadi. Pertama terkait validasi data aset wakaf, termasuk wakaf uang atau wakaf tunai. Kedua, peningkatan pengumpulan wakaf uang. Ketiga, sertifikasi tanah wakaf. Keempat, sengketa tanah wakaf yang memerlukan mediasi dan advokasi serta ruislag (tukar guling) tanah wakaf yang bermasalah. Tantangan kelima, yaitu pemanfaatan aset wakaf untuk kegiatan ekonomi produktif yang memberi nilai tambah bagi

kesejahteraan umat. Keenam, kapasitas dan rasa tanggung jawab para nazir. Tantangan lainnya, yaitu belum meratanya pemahaman wakaf masyarakat terhadap ketentuan Undang-Undang No 41 tahun 2004, khususnya tentang wakaf dan jenisjenis wakaf, belum optimalnya pengelolaan aset tanah wakaf secara produktif, masih banyaknya nazir yang belum profesional, belum tersedianya data base wakaf, serta belum optimalnya jejaring pemberdayaan dan pengembangan wakaf uang.

Setiap bentuk penyerahan suatu benda wakaf maka dilakukan sesuai dengan norma-norma hukum yang berlaku. Peralihan harta benda yang diwakafkan misalkan sebidang tanah untuk menjadi atas nama tanah 
wakaf. Bila surat dari badan pertanahan telah keluar makan telah selesailah hubungan pemilik tanah yang diwakafkan yang terdahulu dengan tanah yang diwakafkan menjadi atas nama wakaf yang telah dibacakan ikrarnya dikantor urusan agama. Peralihan tanah hak milik perseorangan menjadi tanah wakaf merupakan suatu bentuk kepastian hukum akan tidak terjadinya persengketaan dikemudian hari. Badan pertanahan harus memastikan bahwa tanah yang diwakafkan tidak dalam persengketaan atau perbuatan lain yang akan terjadi dikemudian hari. Hal ini yang menjadi poin penting dalam penelitian ini. Tanahtanah yang akan diwakafkan harus bisa dipastikan pada saat perwakafan suatu tanah tidak akan terjadi suatu sengketa baik bagi yang mewakafkan dengan pihak lain yang terkait atas tanah wakaf tersebut. Tanah wakaf ataupun tanah yang diwakafkan harus terlepas dari masalah atas terlanggarnya suatu hak orang lain.

Setiap benda yang di wakafkan perlu dipahami sari segi struktur suatu benda tersebut Sehingga dalam perwakafan atas tanah tidak muncul suatu peristiwa dikemudian hari yang merugikan pihak pengelola tanah wakaf. Memberikan wakaf berupa uang tunai sehingga masyarakat sekitar sehingga perlindungan dan perdamaian. tunai dapat yang menjadi kewenangan syar'i, misalnya uang yang dihibahkan digunakan sebagai sehingga secara hukum sudah tidak dapat dibuang dan yang dihibahkan merupakan hasil dari upaya yang dilakukan melalui nazhir / manajer.

Selain uang dan tanah penyerahan wakaf dapat dilakukan dengan beraneka macam dari segi penyerahan ataupun jenis suatu barang diwakafkan. Wakaf saham pada suatu perusahaan juga dipandang sebagai wujud penyerahan wakaf yang secara modern dalam sumber pendapatan wakaf. Berbagi juga keterampilan sertifikat yang menunjukkan bukti kepemilikan suatu organisasi dan pemegang hak untuk menyatakan atas pendapatan dan aset perusahaan. $^{4}$

Berdasarkan hal tersebut bahwa suatu pemberian wakaf tidak saja dipandang sebagai bentuk penyerahan sebidang tanah namun berkaitan dengan saham yang terlepas dari riba ataupun bentuk pelanggaran terhadap nilai-nilai agama serta hukum yang berlaku. Pemilik modal memberikan uang tunai secara penuh dalam satu kegiatan usaha komersial, dalam hal bisnis untuk dilakukan kepada manajer untuk memanfaatkan harta benda yang dikelolanya, dan

supervisor berkewajiban untuk memberikan kompensasi kepada pemilik properti. ${ }^{5}$ Secara konseptual SBSN identik dengan Surat Utang Negara, khususnya surat berharga yang berstruktur surat utang, masingmasing dalam rupiah dan valuta asing, dimana biaya kompensasi / margin dan pokok dijamin dengan menggunakan negara sesuai dengan ketentuan yang berlaku. masa berlaku.

Berkaitan dengan keanekaragaman dalam pemberian suatu benda wakaf maka dapat diketahui telah terjadi suatu stigma

4 Jaih Mubarok, Wakaf Produktif (Bandung: Simbiosa Rekatama Media, 2008). Hlm, 129.

${ }^{5}$ Ibid. 
pembaharuan dalam mengetahui sumber dana wakaf. Sumber pendapatan wakaf perlu dipandang secara hukum dan memahami segala bentuk serta sumber dalam dana wakaf. Melalui pembaharuan dalam sumber wakaf maka dapat dipastikan kemajuan dalam pengelolaan yang dilakukan oleh Nazir serta lembaga pengelola wakaf membutuhkan suatu kemahiran dalam menggunakan dan menerapkan wakaf bagi kemaslahatan umat islam. Namun pada praktenya masalah sosial dapat terjadi yang tidak dapat dihindarkan yang memberikan suatu problema hukum yang berlaku di suatu masyarakat. Setiap aturan hukum yang dibuat bertujuan untuk memberikan suatu keadilan dan kepastian dalam

penerpannya. Hukum tentu menghindari terjadinya suatu pertentangan tauran hukum yang berlaku sehingga dalam hal ini perlunya suatu ketentuan aturan hukum yang secara pasti memberikan suatu jaminan terlaksananya aturan hukum secara baik. Dengan memahami suatu ketentuan aturan hukum yang berlaku maka dalam penyerahan suatu wakaf akan ditetukan berdasarkan aturan hukum yang berlaku bagi penyerahan serta penggunaan suatu benda yang akan diwakafkan dengan menjadikan suatu obyek wakaf berdasarkan pada

ketentuan hukum yang belaku.Melalui penerapan suatu aturan hukum yang baik maka setiap masyarakat akan memahami dalam menjadikan tanah sebagai obyek penyerahan suatu wakaf.

Berdasarkan penelitian diatas maka penulis mengangap pengalihan hak atas tanah menjadi tanah wakaf merupakan suatu persoalan penting untuk diangkat karena berkaitan dengan akibat hukum dari pengalihan hak atas tanah menjadi tanah wakaf. Sehingga dalam hal ini penulis berkeinginan untuk meneliti dan mengangkat judul Pelaksanaan

Pengalihan Hak Atas Tanah Menjadi Tanah Wakaf (Studi Di Kantor Urusan Agama Keacamatan Datuk Bandar Kota Tanjung Balai).

2. METODE PENELITIAN Metode penelitian adalah cara

ilmiah yang dipergunakan oleh peneliti untuk mendapatkan data-data yang dikehendaki. "Cara ilmiah berarti bahwa kegiatan-kegiatan yang dilakukan diandasi oleh metode keilmuan yang telah teruji. Untuk menjamin ditemukannya kebenaran ilmiah, metode penelitian memberikan cara-cara kerja yang sangat cermat dan syarat-syarat yang sangat keras. ${ }^{6}$ Dengan demikian berarti metode penelitian tidak saja bertujuan memberikan peluang sebesar-besarnya bagi pengetahuan kebenaran yang obyektif, tetapi juga untuk menjaga agar pengetahuan dan pengembangannya memiliki nilai ilmiah yang tinggi.

Jenis Penelitian Berdasarkan perumusan masalah dan tujuan penelitian, maka metode pendekatan yang digunakan adalah pendekatan empiris digunakan untuk menganalisis hukum yang dilihat sebagai prilaku masyarakat yang yang

berkaitan dengan Pelaksanaan Pengalihan Hak Atas Tanah Menjadi Tanah Wakaf (Studi Di Kantor

\footnotetext{
${ }^{6}$ Hadari Nawawi, Metode Penelitian Sosial, ed. Gajah Mada Press (Yogyakarta, 1985).
} 
Urusan Agama Keacamatan Datuk Bandar Kota Tanjung Balai).

Lokasi penelitian dilakukan di Kota Tanjung Balai, yakni pada Kantor Kantor Urusan Agama Keacamatan Datuk Bandar Kota Tanjung Balai, dipilihnya Kantor Urusan Agama Keacamatan Datuk

Bandar Kota Tanjung Balai ini mengingat objek penelitian yang akan dilakukan berkenaan dengan Pelaksanaan Pengalihan Hak Atas Tanah Menjadi Tanah Wakaf (Studi

Di Kantor Urusan Agama Keacamatan Datuk Bandar Kota Tanjung Balai), sehingga dengan demikian sangat memudahkan peneliti untuk mendapatkan informasi atau data yang berhubungan dengan Pelaksanaan Pengalihan Hak Atas Tanah Menjadi Tanah Wakaf (Studi Di Kantor Urusan Agama Keacamatan Datuk Bandar Kota Tanjung Balai).

Sumber data yaitu berkaitan dengan data-data yang dibutuhkan dalam menemukan jawaban atas permalasahan yang peniti akan dalam judul skripsi ini. Data yang didapatkan terdapat dari berbagi segi baik secara pustaka maupun data lapangan yang disesuaikan dengan kebutuhan penelitian ini. Keabsahan suatu data sangat diperlukan dalam suatu penelitian demi mendukung suatu kebenaran dari data yang diperoleh. Sehingga penelitian ini murni merupakan suatu kajian ilmiah.

Di dalam menemukan suatu bahan hukum Soerjono Soekanto membagi penemuan sumber data terbagi atas tiga bagian yaitu: a. Bahan hukum primer, bahan hukum yang diperoleh dari data lapangan dengan melakukan suatu metode wawancara terhadap seseorang yang berkaitan serta berhubungan langsung di dalam suatu penelitian ini. Dengan melakukan penilaian atas hasil wawancara dengan mengumpulkan beberapa orang untuk dilakukan suatu payah wawancara. b. Bahan hukum sekunder, berakiatan dengan bukubuku menjadi petunjuk dalam menyelesaikan permasalahan yang diteliti. Buku tersebut dikumpulkan dan dilakukannya suatu perbandingan dengan mengambil berupa kutipan demi memperkuat setiap narasi menemukan suatu jawaban atas ustau permasalahan hukum yang sedang dihadapai. c. Bahan hukum tersier, ialah perpaduan dari dua bahan hukum dengan melakukan suatu perseuaian demi menemukan titik permalasahan yang sedang diteliti. Ketika titik permasalahan tersebut telah ditemukan maka dilakukan solusi dari permasalahan tersebut

dengan memberikan kepastian terhadap setiap data yang dimiliki.

Teknik Pengumpulan Data Melalui riset lapangan serta studi kepustakaan maka akan dikumpulkan keseluruhan data tersebut dan disusun secara sistematis hingga data terbut terdapat letak permasalahan tersebut.

Setelah permasalahan tersebut didapatkan maka upaya selanjutnya menemukan suatu jawaban dari permasalahan tersebut. Kemudian membuatkan saran maupun opini bagi setiap penegak hukum dan menjadi bahan masukan serta kajian bagi para penegak hukum serta pembaca untuk menjadikan tulisan ini menjadi bahan yang sangat bermanfaat dan berguna.

Analisis Data Didalam melaukan suatu analisis data maka data-data yang diperoleh dilakukan suatu pengkajian hukum. Pengkajian hukum yang dilakukan secara 
menyeluruh dengan fakta yang terjadi dimasyarakat. Melalui penganalisisan ini dilakuan suatu hipotesa dengan

kesimpulan sementara terhadap permasalahan yang terjadi. Sehingga dengan ini digambarkan secara abstrak judul penelitian yang diangkat dan akan disipulkan secara kerucut menjadi suatu data kebenaran.

Persesuaian data ini memberikan persamaan dalam menentukan desolen dan desain

dengan apa yang terjadi sesungguhnya dilapangan dengan segala sesuatunya yang tertulis di dalam hukum yang terkodifikasi. Sehingga melalui hal tersebut akan diketemukan penentuan jawaban atas hipotesa sementara dengan menlanjutkan kelengkapan data dan menyimpulkan secara keseluruhan.

\section{HASIL DAN PEMBAHASAN Pelaksanaan Perubahan Hak Milik Atas Tanah Menjadi Hak Wakaf di Kantor Urusan Agama Kecamatan Datuk Bandar.}

Setelah penulis adakan penelitian dan wawancara dengan beberapa orang yang terkait dengan penelitian ini. Adapun hasil dari pada penelitian ini diantaranya: 7 "Tata Cara Perwakafan Tanah Milik Di Kecamatan Datuk Bandar ialah dengan menyiapkan beberapa syarat saat datang kekantor kecamatan dengan membawa surat tanda kepemilikan berupa surat keterangan PHGR surat lurah dan camat yang dikeluarkan. Apabila tanah yang akan diwakafkan berupah tanah yang telah memiliki sertifikat hak milik, maka

7 Wawancara Dengan KUA Datuk Bandar (2 November 2020), n.d. orang yang mewakafkan diwajibkan untuk membawa sertifikat hak milik yang dikeluarkan oleh Badan Pertanahan Nasional". 8

Tanah wakap harus di sertifikatkan karena dalam prakteknya perwakafan yang banyak dilakukan secara konvensional, hal ini akan menimbulkan berbagai masalah dan tidak sedikit yang berakhir di pengadilan. Hal ini dapat dibuktikan dengan adanya suatu sengketa dikemudian hari jika para ahli waris ataupun dari pihak orang lain melakukan penyimpangan terhadap benda-benda wakaf serta tidak mengakui adanya ikrar wakaf. ${ }^{9}$

Didalam perwakafan sebuah benda tidak bergerak seperti tanah dibutuhkan satu keabsahan atas kepemilikan hak atas tanah tersebut. Kekuatan alas hak tertinggi atas kepemilikan satu tanah adalah dengan memengang status kepemilikan sertifikat Hak Milik. Ada suatu peristiwa yang terjadi diwilayah hukum kecamatan datuk bandar, dimana ahli waris menggugat tanah wakaf yang telah diwakafkan oleh pewaris kekantor urusan agama kecamatan datuk bandar. Kejadian itu bermula Ada tanah wakaf yang di gugat oleh ahli waris pada tahun 2019 yang yang berakhir dipengadilan dan dimenangkan oleh pihak penggugat karena bukti yang sah tidak lengkap. Hal ini perlu menjadi perhatian bersama kepada setiap pihak yang hendak mewakafkan tanahnya perlu memperhatikan beberapa ketentuan yang berpegaruh terhadap status tanah tersebut yang diwakafkan yaitu pada saat terjadi suatu wakaf dengan 
dampak yang terjadi dimasa yang akan datang. Dengan didukung status kepemilikan hak yang sah mutlak dan akurat dalam perwakafan tanah sangatlah dibutuhkan. ${ }^{10}$

Pada pelaksanaannya wakaf dikator urusan agama kecamatan datuk bandar kegiatan perwakafkan dilakukan dengan memenuhi sutau ketentuan dengan beberapa Jumlah Saksi dalam mengikrarkar wakap dihadapan PWAIW. Jumlah Saksi dalam mengikrarkar wakap dihadapan PWAIW 2 (dua) ornag Saksi laki-laki. Kemudian bidang tanah wakaf yang telah diwakapkan di Kecamatan Datuk Bandar yaitu Tanah wakaf yang telah diwakapkan di Kecamatan Datuk Bandar sebayak 25 (dua puluh lima) bidang tanah. Dengan jumlah penduduk yang berada diwilayah hukum kecamatan datuk bandar yang terdiri dari 5 (lima) Kelurahan yaitu :

Kelurahan Sijambi, Kelurahan Pahang, Kelurahan Pantai Johor, Kelurahan Gading, dan Kelurahan Sirantau dengan Jumlah Penduduk 36.547 jiwa dan 8.007 Kepala Keluarga. 11

Adapun bidang tanah yang diwakafkan dengan status terkuat dan terpenuh yaitu Tanah wakap yang telah disertifikatkan sejumlah 9 (sembilan) Bidang tanah. Masih ada tanah wakap yang belum disertifikatkat karena masih banyak masyarakat masih kurang memahami mengenai aturan-aturan yang telah ditetapkan oleh Pemerintah sebagai dasar untuk mendapatkan perlindungan hukum. Proses mensertifikatkan tanah wakaf ke Badan Pertanahan Negara setempat
Badan kenajiran atau pewakaf mendaftarkan tanah wakap dengan membawa persyaratan $:^{12}$

Berkas wakaf dari KUA yang terdiri dari : a. Surat Tanah Kepemilikan. b. Surat Pengusulan Nazir. c. Surat Keterangan wakaf dari lurah. d. Foto Copy KTP orang yang berwakaf, kenaziran, dan ahli waris. e. Ikrar Wakaf orang yang berwakaf dan Kemudian selanjutnya ada beberapa Faktor yang menyebabkan masih banyaknya tanah wakap yang belum didaftarkan: ${ }^{13}$

Berikut ini meruapakan data pertanahan yang masuk pada kantor urusan agama kecamatan datuk bandar untuk diwakafkan namun masih ada tanah-tanah yang belum memiliki sertifikat hak milik pada saat melaksanakan proses wakaf:

\section{Tabel 1}

Data Tanah Wakaf Kantor Urusan Agama Kecamatan Datuk

\section{Bandar}

Provinsi : Sumatera Utara

Kota : Tanjungbalai

Kecamatan : Datuk Bandar

\begin{tabular}{|r|l|c|c|}
\hline No & \multicolumn{1}{|c|}{ Nama } & $\begin{array}{c}\text { Luas } \\
\text { Tanah } \\
\text { Wakaf }\end{array}$ & $\begin{array}{c}\text { Keterangan } \\
\text { Tanah } \\
\text { Sertifikat }\end{array}$ \\
\hline 1 & H.Mulya NST & 1258 & Sertifikat \\
\hline 2 & M.Idris & 1796 & $\begin{array}{c}\text { Belum } \\
\text { Sertikat }\end{array}$ \\
\hline 3 & Syahman & 250 & $\begin{array}{c}\text { Belum } \\
\text { Sertikat }\end{array}$ \\
\hline 4 & Djumium & 280 & $\begin{array}{c}\text { Belum } \\
\text { Sertikat }\end{array}$ \\
\hline 5 & Drs.Kani & 450 & $\begin{array}{c}\text { Belum } \\
\text { Sertikat }\end{array}$ \\
\hline 6 & Zakaria & 725 & $\begin{array}{c}\text { Belum } \\
\text { Sertikat }\end{array}$ \\
\hline 7 & Abdurrahman & 725 & Sertifikat \\
\hline 8 & H.Ibrahim & 250 & Sertifikat \\
\hline 9 & Sumito & 1575 & $\begin{array}{c}\text { Belum } \\
\text { Sertikat }\end{array}$ \\
\hline
\end{tabular}
12 Ibid.
${ }^{13}$ Ibid. 


\begin{tabular}{|c|c|c|c|}
\hline 10 & DTM.Nukman & 1634 & $\begin{array}{l}\text { Belum } \\
\text { Sertikat }\end{array}$ \\
\hline 11 & Sofyan & 400 & Sertifikat \\
\hline 12 & $\begin{array}{ll}\text { Drs. } & \text { Abdul } \\
\text { Hayyi } & \\
\end{array}$ & 250 & $\begin{array}{l}\text { Belum } \\
\text { Sertikat }\end{array}$ \\
\hline 13 & Sumito & 1575 & $\begin{array}{l}\text { Belum } \\
\text { Sertikat }\end{array}$ \\
\hline 14 & Ngaliwon & 350 & $\begin{array}{l}\text { Belum } \\
\text { Sertikat }\end{array}$ \\
\hline 15 & $\begin{array}{ll}\text { Drs. } & \text { Abdul } \\
\text { Hayyi } & \\
\end{array}$ & 775 & Sertifikat \\
\hline 16 & $\begin{array}{ll}\text { M. } & \text { Yusuf } \\
\text { Siagian } & \\
\end{array}$ & 225 & $\begin{array}{l}\text { Belum } \\
\text { Sertikat }\end{array}$ \\
\hline 17 & Khalil & 2.399 & Sertifikat \\
\hline 18 & $\begin{array}{ll}\text { M. } & \text { Yusuf } \\
\text { Siagian } & \\
\end{array}$ & 264 & Sertifikat \\
\hline 19 & $\begin{array}{l}\text { Aspan } \\
\text { Dalimunte }\end{array}$ & 400 & Sertifikat \\
\hline 20 & Hasanuddin & 1.940 & Sertifikat \\
\hline 21 & M.Yasin & 450 & $\begin{array}{l}\text { Belum } \\
\text { Sertikat }\end{array}$ \\
\hline 22 & Zainuddin & 250 & $\begin{array}{l}\text { Belum } \\
\text { Sertikat }\end{array}$ \\
\hline
\end{tabular}

Sumber : Data Tanah Wakaf Kantor Urusan Agama Kecamatan Datuk Bandar

Berdasarkan keterangan tabel tersebut maka dapat diambil suatu hipotesa kesimpulan sementara bahwa pihak nazir wajib untuk segera melakukan pendaftaran status tanah yang diwakafkan menjadi status kepemilikan tanah wakaf. Sehingga dikemudian hari tidak ditimbulkan suatu permasalahan hukum berupa gugatan atas tanah yang diwakafkan dengan memberikan suatu kepastian hukum serta kekuatan hukum yang baru atas tanah yang diwakafkan. ${ }^{14}$

Pelaksanaan Perubahan Hak Milik Atas Tanah Menjadi Hak Wakaf di Kantor Urusan Agama Kecamatan Datuk Bandar. Pada pelaksanaannya wakaf dikator urusan agama kecamatan datuk bandar kegiatan perwakafkan dilakukan dengan memenuhi sutau ketentuan dengan beberapa Jumlah Saksi dalam mengikrarkar wakap dihadapan PWAIW. Hak milik adalah "yang paling efektif dari banyak hak atas tanah. Hak milik adalah hak yang dapat diwariskan dari oleh pewaris kepada ahli waris dan secara terus menerus tanpa adanya kebutuhan suatu hambatan dalam hal terjadi pengalihan hak kepemilikan ".15 Sehingga apabila dilakukan suatu pengalihan suatu hak atas tanah hak milik menjadi tanah wakaf maka perlu adanya ketentuan hukum pengalihan hak atas tanah. Dengan Jumlah Saksi dalam mengikrarkar wakap dihadapan PWAIW 2 (dua) ornag Saksi laki-laki. Kemudian bidang tanah wakaf yang telah diwakapkan di Kecamatan Datuk Bandar yaitu Tanah wakaf yang telah diwakapkan di Kecamatan Datuk Bandar sebayak 25 (dua puluh lima) bidang tanah. Dengan jumlah penduduk yang berada diwilayah hukum kecamatan datuk bandar yang terdiri dari 5 (lima) Kelurahan yaitu :

Kelurahan Sijambi, Kelurahan Pahang, Kelurahan Pantai Johor, Kelurahan Gading, dan Kelurahan Sirantau dengan Jumlah Penduduk 36.547 jiwa dan 8.007 Kepala Keluarga. $^{16}$ Adapun bidang tanah yang diwakafkan dengan status terkuat dan terpenuh yaitu Tanah wakap yang telah disertifikatkan sejumlah 9 (sembilan) Bidang tanah. Masih ada tanah wakap yang belum disertifikatkat karena masih banyak masyarakat masih kurang memahami mengenai aturan-aturan yang telah

15 Moh Hatta, Bab-Bab Tentang Perolehan Dan Hapusnya Hak Atas Tanah, (Yogyakarta: Liberty, n.d.). Hlm, 1.

16 Wawancara Dengan KUA Datuk Bandar (2 November 2020). 
ditetapkan oleh Pemerintah sebagai dasar untuk mendapatkan perlindungan hukum. "Penerbitan sertifikat, yang menunjukkan bahawa pendaftaran tanah telah dilakukan". 17

\section{Hambatan Yang Dihadapi Oleh \\ Kantor Urusan Agama \\ Kecamatan Datuk Bandar \\ dalam pendaftaran dan \\ Perubahan Hak Milik Atas \\ Tanah menjadi Hak Wakaf. \\ Adapun yang menjadi suatu}

hambatan dalam pelaksanaan

pendaftaran dan perubahan hak milik atas tanah menjadi tanah wakaf yaitu tanah yang sudah diwakafkan oleh masyarakat kepada KUA Datuk Bandar masih banyak yang belum didaftarkan ke Badan Pertanahan Nasional. Tanah wakaf yang belum didaftarkan ke BPN dikarenakan

keterbatasan waktu karena membutuhkan proses dalam peralihan atas tanah hak milik pribadi menjadi tanah wakaf. Kemudian tanah yang mau didaftarkan kepihak BPN tentu membutuhkan biaya dalam pengurusan administrasi pendafataran tanah wakaf. Hal inilah hambatanhambatan yang dialami oleh KUA Datuk Bandar dalam pengurusan surat tanah menjadi tanah wakaf.

Kemudian ada faktor lainnya yang membuat proses pendaftaran tanah hak milik menjadi tanah wakaf mengalami suatu hambatan, dimana

\footnotetext{
17 Bahmid, Irda Pratiwi,

"Penyelesaian Sengketa Atas Kepimilikan Alas Hak Atas Tanah Rangkap Dengan Objek Fisik Tanah Yang Sama Studi Putusan Mahkamah Agung Nomor 2902 K/Pdt/2014," Prosiding Seminar Nasional Multidisiplin Ilmu Universitas Asahan ke-4 Tahun 2020 Tema: "Sinergi Hasil Penelitian Dalam Menghasilkan Inovasi Di Era Revolusi 4.0" Kisaran, 19 September 2020, no. September (2020): 686-692.
}

hambatan tersebut didasarkan pada keterbatasan masyarakat itu sendiri serta kesiapan KUA Datuk Bandar dalam mengelola tanah wakaf dari masyarakat. Adapun faktor lain tersebut.

Dengan demikian maka dapat dipahami bahwa pengahambat dalam proses perwakafan atas tanah hak milik didasarkan kepada peningkatan pemaham masyarakat itu sendiri dalam melaksanakan suatu tertib administrasi. Kemudian didukung dari pihak KUA Datuk Bandar dalam hal perwakafan tanah hak milik menjadi tanah wakaf perlunya dilakakukan penataan tanah-tanah untuk dilakukan perubahan hak milik menjadi tanah wakaf melalui prosedur pendaftaran tanah secara sistematik ataupun sporadik kepada Badan Pertanahan Nasional. Sehingga tanah-tanah yang diwakafkan telah memenuhi prosedur ketentuan hukum dalam administrasi suatu pendaftaran tanah. "Pelaksaanaan pendaftaran tanah di Kota Tanjung balai berpengaruh positif atas tata tertib pertanahan, khususnya terhadap tertib hukum dan tertib administrasi pertanahan, yang ditunjukkan dengan banyaknya bidang tanah yang telah dinyatakan layak untuk disertifikatkan dalam proses pendaftaran tanah ini". 18

\section{KESIMPULAN}

Pelaksanaan Perubahan Hak Milik Atas Tanah Menjadi Hak Wakaf di Kantor Urusan Agama Kecamatan Datuk Bandar. Pada pelaksanaannya wakaf dikator urusan

18 Irda Pratiwi Nanda Sagara, Bahmid, "Efektivitas Pendaftaran Tanah Sistematis Lengkap (Studi Di Kantor Atr/Bpn Kota Tanjungbalai)," Jurnal Tectum, Universitas Asahan. 1, no. 1 (2019): 57-60. 
agama kecamatan datuk bandar kegiatan perwakafkan dilakukan dengan memenuhi sutau ketentuan dengan beberapa Jumlah Saksi dalam mengikrarkar wakap dihadapan PWAIW. Jumlah Saksi dalam

mengikrarkar wakap dihadapan PWAIW 2 (dua) ornag Saksi laki-laki. Kemudian bidang tanah wakaf yang telah diwakapkan di Kecamatan Datuk Bandar yaitu Tanah wakaf yang telah diwakapkan di Kecamatan Datuk Bandar sebayak 25 (dua puluh lima) bidang tanah. Dengan jumlah penduduk yang berada diwilayah hukum kecamatan datuk bandar yang terdiri dari 5 (lima) Kelurahan yaitu :

Kelurahan Sijambi, Kelurahan Pahang, Kelurahan Pantai Johor, Kelurahan Gading, dan Kelurahan Sirantau dengan Jumlah Penduduk 36.547 jiwa dan 8.007 Kepala Keluarga. Adapun bidang tanah yang diwakafkan dengan status terkuat dan terpenuh yaitu Tanah wakap yang telah disertifikatkan sejumlah 9 (sembilan) Bidang tanah. Masih ada tanah wakap yang belum disertifikatkat karena masih banyak masyarakat masih kurang memahami mengenai aturan-aturan yang telah ditetapkan oleh Pemerintah sebagai dasar untuk mendapatkan perlindungan hukum.

$$
\text { Hambatan Yang Dihadapi }
$$

Oleh Kantor Urusan Agama Kecamatan Datuk Bandar dalam pendaftaran dan Perubahan Hak Milik Atas Tanah menjadi Hak Wakaf. Adapun yang menjadi suatu hambatan dalam pelaksanaan pendaftaran dan perubahan hak milik atas tanah menjadi tanah wakaf yaitu tanah yang sudah diwakafkan oleh masyarakat kepada KUA Datuk Bandar masih banyak yang belum didaftarkan ke
Badan Pertanahan Nasional. Tanah wakaf yang belum didaftarkan ke BPN dikarenakan keterbatasan waktu karena membutuhkan proses dalam peralihan atas tanah hak milik pribadi menjadi tanah wakaf. Kemudian tanah yang mau didaftarkan kepihak BPN tentu membutuhkan biaya dalam pengurusan administrasi pendafataran tanah wakaf. Hal inilah hambatanhambatan yang dialami oleh KUA Datuk Bandar dalam pengurusan surat tanah menjadi tanah wakaf. Dengan demikian maka dapat dipahami bahwa pengahambat dalam proses perwakafan atas tanah hak milik

didasarkan kepada peningkatan pemaham masyarakat itu sendiri dalam melaksanakan suatu tertib administrasi. Kemudian didukung dari pihak KUA Datuk Bandar dalam hal perwakafan tanah hak milik menjadi tanah wakaf perlunya dilakakukan penataan tanah-tanah untuk dilakukan perubahan hak milik menjadi tanah wakaf melalui prosedur pendaftaran tanah secara sistematik ataupun sporadik kepada Badan Pertanahan Nasional. Sehingga tanah-tanah yang diwakafkan telah memenuhi prosedur ketentuan hukum dalam administrasi suatu pendaftaran tanah. Perlunya pemberitahuan dalam bentuk sosialisasi kepada masyarakat kecamatan datuk bandar mengenai proses perwakafan tanah untuk kepentingan amal ibadah. Perlunya pembentukan pengawasan oleh masyarakat terhadap pengelolaan harta yang diwakafkan.

\section{DAFTAR}

\section{PUSTAKA Buku}

Bahmid,IrdaPratiwi.

"Penyelesaian Sengketa Atas

Kepimilikan Alas Hak Atas Tanah Rangkap Dengan 
Objek Fisik Tanah Yang Sama

Studi Putusan Mahkamah Agung Nomor 2902 K/Pdt/2014." Prosiding Seminar Nasional Multidisiplin Ilmu Universitas Asahan ke-4 Tahun 2020

Tema: "Sinergi Hasil Penelitian Dalam Menghasilkan Inovasi Di Era Revolusi 4.0" Kisaran, 19

September 2020, no. September (2020): 686-692.

Hadari Nawawi. Metode Penelitian Sosial. Edited by Gajah Mada Press. Yogyakarta, 1985.

Jaih Mubarok. Wakaf Produktif. Bandung: Simbiosa Rekatama Media, 2008.

MohHatta. Bab-Bab Tentang Perolehan Dan Hapusnya Hak Atas Tanah,. Yogyakarta: Liberty, n.d.

Nanda Sagara, Bahmid, Irda Pratiwi. "Efektivitas Pendaftaran Tanah Sistematis Lengkap (Studi Di Kantor Atr/Bpn Kota Tanjungbalai)." Jurnal Tectum, Universitas Asahan. 1, no. 1 (2019): 5760.

Zaid Afif. "Peranan Pejabat Pemerintahan Desa Sebagai Pihak Yang Mengetahui Tentang Jual Beli Tanah (Study Di Desa Gotting Sidodadi Kecamatan Bandar Pasir Mandoge Kabupaten Asahan Sumatera Utara)." Prosiding Seminar Nasional Multidisiplin Ilmu Universitas Asahan 2018 Tema : "Strategi Membangun Penelitian Terapan yang Bersinergi dengan Dunia Industri, Pertanian dan Pendidikan dalam Meningkatkan Daya Saing Global" 06 November 2018, Kisaran, no. November (2018): 463-472.

Jumhur Ulama Dari Mazhab Syafi'i, Maliki Dan Hanbali, n.d.

Menurut Pasal 6 Undang-Undang Nomor 41 Tahun 2004 Tentang Wakaf., n.d.

Wawancara Dengan KUA Datuk Bandar (2 November 2020), n.d. 